\title{
ТЕОРІЯ СУЧАСНОЇ ЛІНГВОПЕРСОНОЛОГІї: PIBНI Й КАТЕГОРІї
}

\author{
АНАТОЛІЙ ЗАГНІТКО \\ Український мовно-інформаційний фонд Національної академії наук України, \\ Київ - Україна; Донецький національний університет, Вінниця — Україна \\ НАДІЯ ЗАГНІТКО \\ Донецький національний університет, Вінниця — Україна \\ TEORIA WSPÓŁCZESNEJ LINGWOPERSONOLOGII: \\ POZIOMY I KATEGORIE \\ ANATOLIJ ZAHNITKO \\ Ukraiński Fundusz Językowo-Informacyjny Narodowej Akademii Nauk Ukrainy, \\ Kijów - Ukraina; \\ Doniecki Uniwersytet Narodowy, Winnica - Ukraina \\ NADZIEJA ZAHNITKO \\ Doniecki Uniwersytet Narodowy, Winnica — Ukraina
}

STRESZCZENIE. W artykule zostały wyróżnione i opisane podstawowe poziomy lingwopersonologii. Określono status kategorii osobowości i świadomości językowej, a także narodowego językowego obrazu świata oraz narodowo-kognitywnego obrazu świata jako fundamentalnych kategorii lingwopersonologii. Szczególną uwagę w tym kontekście zwrócono na poglądy traktujące o lingwistycznej kategorii znaczenia leksykalnego. Podjęta została próba określenia prawidłowości i wzajemnych relacji między poziomami komunikacyjnym, uzualnym i językowym, tworzącymi strukturę lingwopersonologii.

\section{MODERN LANGUAGE PERSONALITY THEORY: LEVELS AND CATEGORIES}

\author{
ANATOLY ZAHNITKO \\ Ukrainian Lingual-Informational Fund of the National Academy of Sciences of Ukraine, \\ Kyiv - Ukraine; \\ Donetsk National University, Vinnytsia — Ukraine \\ NADIYA ZAHNITKO \\ Donetsk National University, Vinnytsia - Ukraine
}

ABSTRACT. Basic levels of language personality theory have been determined, and the status of categories of linguistic identity, linguistic consciousness, national-language mapping picture of the world, national-cognitive mapping of the world as core categories of language personality theory has been identified. Particular attention has been focused on considering the linguistic category of lexical meaning in the structure of the language personality theory. Regularities of communicative, usus and speech levels ratio in the language personality theory have been defined. но опрацьовуваних напрямів, що мотивовано можливостями адекватно застосувати антропоцентричний (антропоцентровий) підхід у його корелятивності / некорелятивності системоцентричному. 
Антропологійний підхід уперше обгрунтовано у філософії, звідки перенесено основні його постулати й принципи в лінгвістику, у межах якої він опрацьовуваний у концептуальному розумінні мови та ії відношенні до людини. Останнє зумовило формування двох діад: 1) людина ↔мова й 2) мова $\leftrightarrow$ людина.

У межах першої основним $€$ вплив людини на мову, підпорядкування мови запитам особистості та ін., для другої визначальним постає дослідження впливу людської мови на особистість, ііі поведінку, встановлення статусної ролі мови у формуванні індивідуума як мовної особистості ${ }^{1}$.

Діада мова $\leftrightarrow$ людина $є$ визначальною для студіювань, що зорієнтовані на мовну особистість, аналіз їі лексикону, граматикону, дослідження лінгвокультурологійного вияву особистості, визначення комунікативних інтенцій, розкриття помилок мовної особистості, зумовлених активною дією мовних начал, і под. Все це сукупно стало підгрунтям формування особливої сфери наукового пізнання - лінгвоперсонології.

Термін лінгвоперсонологія, на думку багатьох лінгвістів, запропонував В. Нерознак ${ }^{2}$ на позначення наукової дисципліни, де об'єктом є мовна особистість. Для науковця особливим постає відношення мовна особистість ↔ мовний колектив, де перша завжди підпорядкована активному впливу останнього, хоча необхідно враховувати й зворотну дію, оскільки активна особистість 3 іiі мовним потенціалом істотно впливає на загальномовну стихію колективу. Водночас слід враховувати те, що навіть особистість як лідер не може одноососібно, без підтримки інших мовних особистостей, кардинально змінити мовне тло колективу, хоча її вплив у загальному колективному вияві може суттєво варіювати $\rightarrow$ модифікувати $\rightarrow$ трансформувати мовний портрет колективу, що в перспективі може охопити низку такого розрізу студіювань. Більше того, інколи мовні особистості встановлюють мовні пріоритети, мовні цінності не тільки в мовному колективі, а й загальнонародні ↔ загальнонаціональні. Підтвердженням цього $\epsilon$, наприклад, функційний статус мовних особистостей Івана Котляревського, Тараса Шевченка, Івана Франка³, Вука Караджича, Олександра Пушкіна, Юліуша Словацького та ін. Тому цілком мотивованим постає твердження про те, що лінгвістична персонологія досліджує „стан мови (індивідуації) частковолюдської мовної особистості (ідіолектної особистості) й багатолюдської (полілектної) мовної особистості (народу)"4.

Цікавим є те, що магія слова для будь-якого мовця часто постає визначальною: „... вірю в магію слова, в його здатність матеріалізуватися. Старша донька знайомої письменниці несподівано поставила ії перед фактом: „Мамо, я одружуюся і виїжджаю до Словаччини". Мати тільки випалила з гіркотою: „Ну от, вона виходить за словака. Тепер тільки залишається, щоб друга вийшла за американця, і я залишилася сама..." Через два роки хлопець з Америки, наш емігрант, приїхав до Ужгорода, щоб забрати з собою ії молодшу доньку" (М. Дочинець).

${ }^{1}$ Т. С. Плесовских, Лингвоперсонология в контексте антропологического подхода, [в:] „Science Time” 2014, № 4, с. 173-179.

${ }^{2}$ В.П.Нерознак, Лингвистическая персонология: к определению статуса дисциплины, [в:] Язык. Поэтика. Перевод, Москва 1996, с. 112-116.

3 Примітка. Порівн., напр., спостереження над мовною особистістю Івана Франка: Т.А. Космеда, Комунікативна компетенція Івана Франка: міжкультурні, інтерперсональні, риторичні виміри, Львів 2006, с. 124-145.

${ }^{4}$ В. П. Нерознак, Указан. источник, с. 113. 
Виділення Ю. Карауловим ${ }^{5}$ трьох рівнів організації мовної особистості вербально-семантичного, лінгвокогнітивного, мотиваційного — грунтовано на іiі потенційній можливості виявляти себе на кожному з них. Тією чи тією мірою ідеї про особливості реалізації мовною особистістю на кожному з рівнів знайшли розвиток і поглиблення в низці студіювань (В. Карасик ${ }^{6}$, Т. Космеда $^{7}$, I. Стернін ${ }^{8}$ та ін.). Водночас досить грунтовно почали встановлювати закономірності реалізації мовленнєвих потенцій в окремих узусних практиках, що знайшло розвиток в ідеях дискурсивної практики чи дискурсивних практик.

У сучасних дослідженнях активно простежуваними $€$ кілька підходів до аналізу мовної особистості: 1) психологічний (особливості характеру й специфіка його комунікативного вияву); 2) соціологічний (розгляд індикаторів мовної особистості, корпоративних груп і т. ін. та індикаторів комунікативної поведінки мовної особистості, малих груп, встановлення параметрів узусних та мовленнєвих обмежень); 3) культурологійний (моделювання лінгвокультурних типів як упізнаваних національних феноменів на зразок украйнський козак, польський шляхтич, американський бізнесмен); 4) лінгвістичний (комунікативна поведінка носіїв різних суспільних категорій, встановлення параметрів комунікативної поведінки, „розпізнавання” мовленнєво-комунікативних типів, дослідження закономірностей реалізації комунікативних стратегій і тактик, розгляд особливостей вияву мовної особистості в різних їі дискурсах $\left.{ }^{9}\right)$; 5) прагматичний $\leftrightarrow$ прагмалінгвістичний ↔ лінгводискурсивний (визначення різновидів комунікативної тональності ${ }^{10}$. Для лінгводискурсивного підходу функційно навантаженою $є$ множина ознак, кожна з яких має самодостатність для опису мовної особистості за відповідною дискурсивною практикою:

1) одно- / поліплановість смислів;

2) передбачуваність / непередбачуваність (відкритість) реакцій;

3) доцільність / недоцільність спілкування;

4) кооперативність / конфліктність спілкування;

5) пріоритет змісту / форми спілкування;

6) розгорнутість / стислість спілкування;

7) нормативність / ненормативність спілкування;

8) конкретність / абстрагованість спілкування;

9) одно- / багатотематичність спілкування;

10) серйозність / несерйозність (іронія, жарт, сарказм та інше) спілкування;

11) відкритість / закритість спілкування. Для оптимального опису мовної особистості доцільним є розгляд щонайбільшого обсягу дискурсивних практик.

Вагомим $є$ встановлення категорійного апарату лінгвоперсонології. До іiі ядрових категорій належать „мовна особистість”, „мовна свідомість”, з якими пов’язані категорії „мовна картина світу”, „когнітивна картина світу”.

У сучасній лінгвістиці мовну особистість зазвичай витлумачують, як конкретну особистість, що досконало знає мову, усвідомлено й творчо володіє нею, сприймає мову в контексті національної ментальності й культури

${ }_{5}^{5}$ Ю. Н. Караулов, Русский язык и языковая личность. Москва 1987, с. 11-17.

${ }^{6}$ В . И. К ар а с и к, Языковой круг: личность, концепты, дискурсы, Волгоград 2002, с. 187-194.

7 Т. А. Ко с м еда, Комунікативна компетенція Івана Франка..., с. 104-114.

${ }^{8}$ И. А. Стернин. Коммуникативное поведение и проблемы его исследования, [в:] „Русское и финское коммуникативное поведение", Воронеж 2002, вып. 1, с. 4-21.

${ }^{9}$ Примітка. Порівн., напр.: Т. А. Кос ме да, Ego i Alter Ego Tapaca Шевченка в комунікативному просторі щоденникового дискурсу, Дрогобич, 2012, с. 57-68.

${ }^{10}$ См.: В . И. Карас ик, Дискурсивна персонология, [в:] „Язык. Коммуникация и социальная среда", Воронеж 2007, вып. 7, с. 78-86. 
як їхнє духовне осердя, уживає мову як невід'ємний елемент самотворення, самопізнання, самоствердження й самовияву, розвитку та вдосконалення власних інтелектуально-розумових та емоційно-рольових, експресивно-почуттєвих можливостей і як найнеобхідніший засіб соціалізації особистості в людському суспільстві ${ }^{11}$.

За абстрагування та встановлення узагальненого зразка мовної особистості їі модель можна кваліфікувати як сукупність здібностей і характеристик людини, що зумовлюють продукування й розуміння особистістю текстів, що різняться між собою:

1) ступенем мовно-структурної складності;

2) глибиною, послідовністю й точністю вияву дійсності;

3) комунікативною настановою;

4) естетичним навантаженням;

5) психологічним ефектом тощо.

Тому мовна особистість є поєднанням: а) мовної компетенції, б) прагнення до творчого самовияву, в) вільного, автоматичного здійснення усебічної мовленнєвої діяльності, г) гармонійного існування в мовному колективі, г) власної мовної самоідентифікації і т. ін.

Мовна особистість цілком свідомо й відповідально ставиться до власної мовної практики, є виявом соціально-корпоративного, суспільно-культурного, територіально-регіонального середовища, традицій виховання ${ }^{12}$. Вербальне мистецтво (подібне до інших мистецтв (малярство, музика тощо), але водночас $є$ іншим) мовної особистості поєднує й акумулює всі зорові, слухові, дотикові відчуття в слові як специфічному синкретичному й синергетичному знакові. Останнє зумовлює особливе значення мови як чинника формування особистості.

Досліджуючи зв'язок мови 3 мисленням людини, ï внутрішнім світом та культурними цінностями (поч. XIX ст.), В. фон Гумбольдт наголошував на значущості силового ${ }^{13}$ поля мови для особистості, дух якої індивідуум спроможний пізнати тільки усвідомлюючи глибину мовного знака, та функційне навантаження останнього для усіх носіїв мови. Незаперечною є теза: „Між будовою мови й успіхами в інших видах інтелектуальної діяльності наявний беззаперечний взаємозв'язок”14, адже „мова — дзеркало культури”" ${ }^{2}$. Кожний індивідуум формується в ,семантичному полоні мови”, освоюючи та засвоюючи його.

Встановлення особливостей вияву пропонованих ознак у дискурсивних практиках і загалом диференціювання дискурсів за цими кваліфікаційними параметрами має опертям рівневу структурацію лінгвоперсонології, що ніяк не повинна розглядатися спрощено, оскільки в такій структурації істотне навантаження мають усі традиційно виділювані мовні рівні, але в цьому разі йдеться про структурацію, де чинними $є$ і мотивація, й інтенція, й креативність, й експресія, і лексикон, і граматикон, і т. ін.

Ідеї німецького лінгвіста творчо розвивав О. Потебня та ін. Такий підхід закцентував вагомість антропоцентризму, тобто перевагу психологічного (порівн. виділення О. Потебнею психологічного підмета і психологічного присудка,

${ }^{11}$ А. Загнітко, Словник сучасної лінгвістики: поняття і терміни, Донецьк, 2012, т. 2, c. $345-346$.

${ }^{12}$ Там само, с. 345 .

${ }^{13}$ В. Г Гу мб оль д т, Избр. труды по языкозн., Москва 2000, с. 46.

14 Там само, с. 47.

15 Там само, с. 188 . 
кваліфікацію речення як аперцепиії почуттів) та етнопсихологічного (дослідження В. Вундта 3 психології мови) елементів у студіях 3 мови та зосередження уваги на людській особистості як продуцентові мовної картини світу ${ }^{16}$. Це уможливило диференціацію трьох ярусів структурного вияву мовної особистості:

1) нульового — вербально-семантичного (лексикону мовної особистості) 3 відповідним фондом лексичних та граматичних засобів, які особистість використовує під час створення тих чи тих текстів (дискурс мовної особистості, що охоплює різножанрові й різностильові комунікативні одиниці);

2) лінгвокогнітивного (тезаурусу мовної особистості) — простежуване бачення об'єктивного світу (система знань про світ). На цьому рівні значущими постають інтелектуальні характеристики, притаманні картині світу особистості (тезаурусові особистості). Інтелект послідовно виявлюваний у мові, його легко проаналізувати через мову. Цей рівень інколи називають інтелектуальним ${ }^{17}$. Одиницями цього ярусу (тезаурусу) є поняття, слова-символи, образи, уривки фраз, формули, моделі, схеми, ідеї, що виформовані в кожної мовної індивідуальності в упорядковану, певним чином систематизовану індивідуальну картину світу з відповідною ієрархією значущостей і цінностей. Лінгвокогнітивний рівень (тезаурус) збагачується шляхом пізнання світу, унаслідок чого поняття, оцінки конкретної мовної особистості перетинаються й переплітаються 3 етнопсихологічними, соціокорпоративними, національно-культурними властивостями, тому мовна особистість — власне-національний феномен. Знаковим у національній свідомості є ставлення до мови, оцінка іiі як самодостатньої, неповторної, самоідентифікаційної, здатної до загальнокультурного акумулювання знань, надбань і досягнень інших народів, до оптимального вияву національно-мовної картини світу. Національне охоплює всі структурні яруси мовної особистості;

3) мотиваційного (ярусу діяльнісної комунікації), що виявляє особистісний прагматикон (система стратегій, тактик, намірів, мотивів, настанов, виявлювана в процесі творення текстів та в їхньому змісті, а також особливостях сприйняття чужих текстів із визначенням ієрархії цінностей у мовній моделі світу особистості).

Мовну особистість у комунікативній лінгвістиці розглядають як типового, зразкового або самобутнього мовця (носія певної мови), виявлюваного в сукупності його мовленнєвих характеристик - стратегій і тактик.

Опис (портрет) мовної особистості не варто ототожнювати, наприклад, iз описом мови художніх творів певного письменника, тому що слід ураховувати його формальне й неформальне спілкування (зокрема наявність епістолярної спадщини, спогадів очевидців, його перекладознавчу діяльність та ін.) ${ }^{18}$.

Цікавими є спроби зінтерпретувати творчу мовну особистість через характерні дискурсивні практики, порівн.: хобі, забобони, анекдоти ${ }^{19}$ як активно мовно-мовленнєвий зріз сімдесяти майстрів художнього слова — від Володимира Базилевського, Свгена Барана — до Володимира Шавкошитного, Володимира Яворівського. У двохсот десяти майстрово викінчених оповідях — дискурсивних практиках легко впізнаваними постають жартівливість та іронія, глибинна мудрість і молодеча зухвалість, гра з читачем й апеляція до нього.

${ }^{16}$ См.: Т. Б. Радбиль, Основы языкового менталитета, Москва 2010, с. 86-163; Т. И. Домбров ан, Язык в контексте синергетики, Одесса 2013, с. 94-123.

${ }^{17}$ А. З Загні тко, Теорія граматики і тексту, Донецьк, 2014, с. 156-178.

${ }^{18}$ А. З агн і тко, Словник сучасної лінгвістики..., с. 345-346.

${ }^{19}$ Посмішка чорного кота: гобі, забобони, анекдоти, Київ 2011. 
Загальнорівнева структура лінгвоперсонології грунтована на знакових поняттях лінгвоетнічності, комунікативності, когнітивності, соціальності, лінгвокультурологійності, лінгводискурсивності, що уможливлює вирізнення лінгвоетнічного (мовна особистість та етнос), комунікативного (комунікативні інтенції мовної особистості, іï креативність, тактики й стратегії, комунікативна компетенція), когнітивного (національно-когнітивна база, корпоративнокогнітивна множина, концептосфера, концепти й категорії, символи й образи, поняття й смисли мовної особистості, мовного колективу), соціального (соціолінгвістичного (комунікативно-статусні ролі, соціолінгвістичний портрет колективу та ін.), лінгвокультурологійного („лінгвокультурна мотивація” особистості, лінгвокультурні зразки й под.), лінгводискурсивного (комунікативні тональності, комунікативні регістри, маркованість дискурсивними практиками особистості, колективу, типологія дискурсивних практик мовної особистості, первинні й вторинні смисли, ситуативно визначувані смисли тощо) рівнів.

Встановлені ядрові категорії на кожному з рівнів мають особливості свого вираження. Якщо торкатися комунікативного, лінгводискурсивного та інших рівнів загальнонаціональної мовної особистості, вони корелюють із загальнаціональним фондом мовної пам'яті, функційними виявами мови тощо. Загальнонаціональна множина дискурсивних практик знаходить відбиття в тлумачних словниках, за якими легко простежити й динаміку словникового складу, збільшення ємності тих чи тих тематичних угруповань, розширення / звуження семантичного багатства загалом та окремого слова зокрема.

Кожний тлумачний словник є відносним зрізом відносного семантичного простору мови в усіх вимірах. Так, від перших граматик української мови й до найостанніших усталеною є частиномовна класифікація та їі відбиття в різноманітних словниках, особливо там, де наявні різноманітні перехідні площини - словоформа набуває функційно іншого вияву, відповідно по-іншому його розглядають у лексикографії (порівн., напр. (23), (24), (25), (26), (27), (28), $\left.(29)^{20}\right)$.

На початку XX ст. у всі нормативні граматики й відповідно словники увійшло поняття невідмінюваності (див.: (1), (2), (3) і далі), що охоплює іменниковість, прикметниковість, постаючи в них як виняток. Для різноманітних дискурсивних практик семантичні й граматичні реалізації цього корпусу слів $є$ досить показовими, що підверджувано словниковою реальністю.

Для комунікативної компетенції мовної особистості знаковим є або системно нормативне вживання слова / слів у відповідних значеннях (див. ознаку (7)), або ж орієнтування на корпоративні зацікавлення (див. ознаки (4), (11)), або ж обігрування для отримання певного ефекту (див. ознаки (5), (10)).

У цьому разі розглянуто тільки функційно-словникові вияви окремих лексем, оскільки їхній викінчений аналіз вимагає досить широкої площі. Так, наприклад, 3-поміж невідмінюваних слів у сучасній українській мові особливу роль відіграє їхнє функціонування з опертям на відповідну семантику.

Якщо виходити 3 позиційного закріплення невідмінюваних лексем, то легко можна переконатися в наявності цікавих виявів їхньої частиномовної категоризації (тут не заторкнуто питання про нульову відміну цих іменників та наявність 14 омонімійних формально- й семантично-відмінкових форм у систем-

${ }^{20}$ Примітка. Усі наведені в тексті статті ілюстрації (речення) наскрізно пронумеровані для зручності опису та відсилання до них. У дужках з цифровим позначенням уміщені поклики на потрібні ілюстрації, що наведені в тексті. 
ному вияві ${ }^{21}$, про динаміку їхньої диференціації за родами в узусній та мовленнєвій практиках, де використання таких лексем із відповідною категоризацією роду належить до комунікативної компетенції мовної особистості ${ }^{22}$, його соціального / соціально-рольового статусу, наявності колективно інтенційних реалізацій і т. ін.). Для спостереження можна використати кілька лексем: каре, $i$ диго, інженю. Слово каре в сучасних словниках та за інвентарем фактичного матеріалу з Національного корпусу української мови Національної академії наук України ${ }^{23}$ має такі значення: 1) 'невідм., $c$. Бойове шикування піхоти у формі чотирикутника; застосовувалося 3 XVIII ст. перев. для відбиття кавалерійських атак': (1) $)^{24}$ Після того [присяги прапорові] полк знову вишикувався в каре, командир з комісаром стали поруч на поличку тачанки (Ю. Смолич) ${ }^{25}$; (2) Тричі налітали дроздовиі на це маленьке каре, ... але щзоразу на землю падала більшість вершників (П. Панч); (3) Пролунали команди. Загриміли барабани. Сколихнулися $і$ завмерли прямокутники каре, рівні й застиглі, мов витесані із каменю. Блискуча кавалькада придворних і генералів на чолі з імператором рушила вздовж фронту (В. Малик); (4) Наш взвод розвертався в каре - лицем до ворожої кінноти. Передні лягали, ті, щчо позаду, ставали на коліна, а ще задні на весь зріст циілились в уявну кінноту (А. Дімаров); (5) Солдати підійшли, стали навпроти і почали розвертатися в каре, попереду із рипінням викотилися візки із гарматами й каноніри почали розвертати їх, наводячи мідні жерла на козаків (Д. Білий); 2) 'невідм., с. Різновид жіночої зачіски середньої довжини перев. 3 прямою гривкою’: (6) Навіщзо вона постриглася сьогодні? Зробила якесь зовсім коротке каре. Такі зачіски чомусь завжди додають віку (І. Карпа); (7) Каре стало користуватися популярністю після Першої світової війни, зокрема завдяки танцюристизі Ірені Касл (із журн.); 3 ) 'у знач. прикм. У формі чотирикутника': (8) Вивчаю Віку поглядом .. Темні кільия довкола очей, зачіска каре (Любко Дереш); (9) Комір каре. У першому значенні констатовано відтінок 'Про те, що має форму чотирикутника': (10) Посередині каре, на вільному місці плачу, як мушина крапка на шибиі вікна - стояв крихітний аналой (Ю. Смолич); (11) Всього шість n'ятиповерхових будинків, стулившись y каре, оточували двір (О. Ірванець). Перший прискіпливий погляд на увесь фактичний матеріал сигналізує про відносну умовність частиномовно-категорійної кваліфікації семантичного простору лексеми каре. Якщо порівняти (8) зачіска каре, (9) - колір каре як підтвердження прикметникового частиномовного статусу (в реченні каре на формально-граматичному рівні є означенням, грунтованим на формі підрядного прислівного синтаксичного зв'язку слабке прилягання) i (1) — вишикувався в каре, (4) — розвертався в каре, (5) - почали розвертатися в каре, де в усіх випадках конструкція в каре є постдієслівною, що актуалізує семантику дієслова розвертатися і $є$ носієм окремої пропозиції, легко помітити — функційно в каре є 'у знач. присл.'. Подібне твердження

${ }^{21}$ А. П. Загнітко, Типологія категорійної семантики невідмінюваних іменників, [в:] Акиентологія. Етимологія. Семантика, Київ 2013, с. 613-632.

22 Примітка. Якщо враховувати кваліфікаційні ознаки дискурсивних практик у лінгводискурсивному аналізі мовної особистості, вживання іменників нульової відміни може поставати одним з аспектів кваліфікації мовної особистості за кількома такими ознаками (порівн. (2), (4), (6) та ін. ознаки).

${ }^{23}$ А. Загнітко, I. Данилюк, Ж. Краснобаєва-Чорна, О. Путіліна, Г. Сит ар, Парадигмально-категорійні основи прикладної лінгвістики, Вінниця 2015, с. 13-70.

${ }^{24}$ При мітка. Розпочато нумерацію ілюстративного матеріалу.

25 Примітка. Тут і далі тлумачення й приклади почерпнуто з Віртуальної лексикографічної лабораторії Украӥнського мовно-інформаційного фонду Національної академї наук Украӥни. 
легко аргументувати порівнянням із подібними конструкціями в постдієслівній синтаксичній позиції лексеми розвертатися, що марковані підрядним прислівним синтаксичним зв'язком у формі прилягання. Для дієслова розвертатися 3 його десятьма системно закріпленими значеннями семантика 'Повертаючись, змінювати своє положення або напрям свого руху; робити розворот’ у словнику констатована після значення 'розм. Переставати бути згорнутим, скрученим; розгортатися, розправлятися’. За врахування наявності в семантичні структурі дієслівної лексеми розвертатися просторової семи як основної аналізоване значення має бути першим (у цьому разі не розглянуто особливості реалізації просторової семи — нульова / формально виражена, оскільки важливим $\epsilon$ те, що розвертатися можна тільки в межах певного простору): (12) Він [теплохід] зайшов у тиху бухту $і$ став розвертатися (в бухті), щзоб причалити до пристані (В. Собко); (13) Машина в'юнко виписувала віражі, різко змінювала швидкість розверталася на місці (із журн.); (14) Не глянувши на подру2y, Марійка круто розвернулась і швидко подалась до лісу (О. Донченко) - нульове вираження; (15) Пролунала команда, і ми спинились. Потім колона розвернулася й загородила шлях (П. Колесник) - нульове вираження. Функційний вияв в каре є адвербіальним, ідентичним до (16), (17), (18), (19), порівн. також: (16) Ріос ще трохи зачекав на порозі, розвернувшись боком і нахиливши голову (А. Азімов); (17) Переяславські сотні зрештою розвернулись тилом до Вовчого Хвоста (І. Білик); (18) У бушуванні прожектора моряцькі машини розвернулися в ряд (М. Вінграновський); (19) У бушуванні прожектора моряцькі машини розвернулися в ряд (із журн.). У (16) - боком, (17) - тилом, (18) в ряд за особливостями внутрішньореченнєвої позиції підтверджують адвербіальний статус синтаксем, хоча в сучасних лексикографічних тлумачних словниках така реалізація не знаходить відбиття. Винятком можуть бути окремі лексеми зразка кидком, ривком, у яких словники констатують: кидком — 'присл. Швидко кидаючись або швидко кидаючи': (20) Єдиний рятунок для них [оточених] в ияю мить - кинутись кидком саме вперед (О. Гончар); (21) Hе нападав, а підходив. Чому ж підходив? А як саме підходив? Крадькома чи кидком? (В. Фіялко); (22) Юнак миттево очінив всю складність ситуацї - кидком випередив усіх (із журн.); ривком ' $у$ знач. присл. Одним різким коротким рухом; поривчасто’: (23) Він став оглядати мотор, непомітно поставив на місие деталь (раніш зняту). Потім сів на мотоцикл, ривком натиснув ногою - мотор зразу ж завівся (А. Головко); (24) Допаливши цчигарку, рвучким ривком викинув [Мартин] ї̈ за вікно на вулицюю (Г. Епік); (25) Запалившись, Оля з останніх сил, ривком, викручує ногу, і переслідувач... летить сторч головою (Л. Юхвід); (26) Він ривком притягнув до себе Мартариту (О. Авраменко, В. Авраменко); стрибком - 'у знач. присл. Різко змінюючись': (27) Надпровідність полягає в тому, щзо при наднизьких температурах, різних для кожного металу, у них стрибком, практично до нуля, падає опір. Матеріал стає надпровідним (з наук.-попул. літ.). До цього слід додати, що лексеми зразка ривком, стрибком подані у відповідних лексикографічних статтях лексем ривок, стрибок як окремий вияв їхньої семантики. Нижче також наведено в статті іменникової лексеми ривок - ривками - ' у знач. присл. Порушуючи ритм чого-небудь; неритмічно, нерівномірно’: (28) Кашубський ігнорував будь-які планові основи постачання експедииії, вся робота велась ривками, итурмівщиною (Л. Дмитерко) з відтінком 'Неплавно'(29) Щось крикнули з гурту, та Саїд не озирався. Відкрив допоміжний кран пального, і машина ривками понесла в гори (Іван Ле), 
а в статті - стрибок - стрибками: 'у знач. присл. Підскакуючи при переміщенні від поштовхів, коливань і т. ін.', порівн.: (30) Дерев 'яний рибальський човен пливе стрибками (з наук.-попул. літ.). Для мовної особистості з її лексиконом як відбиттям загальнонаціонального істотним $є$ не тільки знання загального семантичного простору слова, але й уміння розпізнавати й упізнавати його категорійно-частиномовну семантику.

Побіжний погляд на виявлюваність лексичного потенціалу слова в сучасних тлумачних словниках свідчить, що категорія лексичного значення має особливий статус у лінгвоперсонології з виявом на комунікативному, лінгводискурсивному, когнітивному рівнях. Лексичне значення співвіднесене з усіма рівнями лінгвоперсонології, навантаження ж відповідних іiі форм спрямоване на перспективу студіювань.

Відбиваючи сукупність більшості загальнонаціональних лінгводискурсивних практик, тлумачний словник спрямований на всеохопність відбиття значення слова. Сумарна кількість функційних виявів словоформи 3 тим чи тим значенням може репрезентувати їі лексемну окремішність (див.: (20), (21)), низька частота реалізації - свідчить про зв'язок з основним (ієрархічно вершинним) значенням і кваліфікацію 'у знач.' (порівн.: (23), (24), (25), (26)).

3 мовною компетенцією пов’язана й кваліфікація невідмінюваних лексем, що можуть у межах свого значення охоплювати іменниковий, прикметниковий, прислівниковий статуси (індиго, ін-фоліо), прикметниковий і прислівниковий (iн-октавіо). Загалом невідмінюваність як мовно-корсетна особливість заслуговує на окремий розгляд у лінгвокреативному й лінгвокогнітивному вимірах лінгвоперсонології, не кажучи про форми на зразок вечорами, веснами, днями, ранками або лексеми 3 максимальним / відносним потенціалом граматизації (imu, nimu, ходити). Перспективними є студії з усіх рівнів мовної особистості та встановленням площин найактивнішої взаємодії ядрових категорій лінгвоперсонології.

Теорія мовних рівнів відкриває перспективи студіювання індивідуальних портретів лексичних, морфологічних, синтаксичних, словотвірних мовних особистостей, функційне навантаження принципів орфографії 26 як поєднання відбиття й умовності та пунктуації ${ }^{27}$ - індивідуальних портретів орфографічних, пунктуаційних мовних особистостей.

Для лінгвоперсонологійних описів істотним є встановлення здібностей носіїв мови $з$ простеженням максимального / мінімального нахилу до варіантності - фонетичної, фонологічної, морфемної, семантичної.

Сучасна лінгвоперсонологія з ііі кількома рівнями, 3-поміж яких найбільш опрацьованими є комунікативний зі спробами визначення типології прагматичних інтенцій, вияву різного характеру девіацій, напрямів реалізації принципів комунікації з їхніми максимами й постулатами, простеженням комунікативних стратегій і тактик, когнітивний із послідовним розглядом певних концептосфер, встановленням співвідношення когнітивних глибин із формально-

${ }^{26}$ См., напр.: Е. Н. Тат ар и н цев в, Лингвоперсонологическое функиионирование приниипов русской орфографии, Автореф. канд. филол. наук, Барнаул 2007, с. 4-14.

27 Примітка. Статус функційно-авторського принципу пунктуації є особливим: він не покривається навантаженням структурного, семантичного й інтонаційно-ритмового. Його вияви в індивідуальному мовленні автора, його дискурсивних практиках розкриває особливості ставлення митця до розділових знаків загалом та їхнього статусу в актуалізації, смисловому творенні зокрема (див.: А. П. Загнтітко, Теоретична граматика украӥнської мови. Морфологія. Синтаксис, Донецьк 2011, с. 525-784). 
А. Загнітко, Н. Загнітко

поверхневими. Останнім часом певного розпросторення набувають студіювання лінгводискурсивних практик, встановленням їхньої національно-мовної специфіки. Особливої уваги потребує розгляд комунікативних — лінгводискурсивних тональностей, лінгводискурсивних регістрів - 3 характеристикою рівнів мовної особистості на кожній з окреслених площин лінгвоперсонології. 